\title{
DOČASNOST ZÁKONA JAKO HODNOTA CHTĚNÁ A NECHTĚNÁ*
}

\author{
MICHAL ŘÍHA
}

\begin{abstract}
Temporality ot the Law as a Wanted and Unwanted Value
Durability and stability of law are values always considered to be inherently connected with principles of good lawmaking. The main reason for this understanding is that they are condition for fairness of law and equality before the court of law. If same situations are decided differently it would mean that fundaments of law itself as a system are endangered. However modern times bring opposite problem - what if different situations are decided the same due to the fact, that factual situation changed but the legislation remained unchanged? The main issue of this paper is covering this problem which shows that even the basic postulates of law sometimes need to be questioned.
\end{abstract}

Keywords: rule of law; temporality; Smart Regulation

Klíčová slova: vláda práva; dočasnost; Smart Regulation

DOI: $10.14712 / 23366478.2020 .4$

\section{1. ÚVODEM}

Právo, coby jeden z hlavních normativních systémů současnosti, prochází významnou proměnou ve vztahu ke svojí temporalitě. Právo původně bylo velmi úzce spojováno s náboženstvím, takže stejně jako byly neměnné teologické postuláty, obdobně neměnné byly i právní konstrukce. Typickým př́kladem je islámská doktrína taklíd spočívající v zákazu zpochybňování závěrů učenců předchozích generací, která byla převzata i tradičním konfuciánstvím do principu sao. Tyto přístupy nabízejí vysokou míru předvídatelnosti práva, ale postupem času je právem rámcovaný prostor stále více zaplněn ${ }^{1}$ a dlouhodobé setrvání na těchto principech vede ke konzervaci nejenom práva, ale i společnosti. Obdobně tomu bylo i v rrímském civilním právu, které také vytvořilo ucelený soubor norem, na což postupem času začaly narážet potřeby mění-

* Tento příspěvek vznikl na základě plné finanční podpory a je výstupem projektu SVV č. 260358 řešeného na PFUK s názvem: „Kritická analýza pramenů práva se zřetelem na problémy jejich interpretace a retroaktivitu“. Č́st textu vychází z rigorózní práce autora.

1 I proto významná část muslimské literatury je věnována tzv. hijal, tedy návodům, jak bud’ obejít či jen formálně dodržet šariátní pravidlo. 
cí se společnosti. Ty si nejdříve vyžádaly jeho modifikaci formou znovuobjevováním „zapomenutých“ norem kněžími² a následně rozvoj i preatorského práva a legislativy.

Moderní liberální pojetí stability práva se opírá o odlišné základy, než má náboženské právo. Jejím hlavním cílem je nikoli dohled nad náboženskými pravidly, ale ochrana práv jednotlivce, který díky stabilitě práva ví, co může od normativního systému (potažmo společnosti) očekávat; jakým způsobem budou dotčena jeho práva a jaké jsou jeho povinnosti chování. Stabilita sice nic neříká o správnosti takové právní normy, nicméně i pravidlo, které může subjektivně působit jako nespravedlivé, je „spravedlivě“ a předvídatelně aplikováno stejně ve všech stejných případech, čímž přispívá principu rovnosti před zákonem coby demokratickému principu. Proto Gustav Radbruch považuje stabilitu práva za předpoklad funkčnosti právního řádu, a to i za cenu ústupku jeho možné nespravedlnosti. ${ }^{3} \mathrm{~V}$ opačném př́ípadě by na stejné situace vzniklé v krátkém časovém sledu byla uplatňována odlišná pravidla, což by dávalo vzniknout jinému druhu nespravedlnosti a de facto nerovnosti před zákonem.

I liberálnímu pojetí stability práva ale začal postupem času konkurovat společenský vývoj. Průmyslová revoluce vedle technologických změn přinesla i významné změny společnosti - urbanizaci, rozbití dosavadních sociálních vazeb či vznik proletariátu které se musely projevit $\mathrm{v}$ právu. Belgický král Leopold II. např́íklad v roce 1886 proklamoval, že ,podminky pracujici třídy vyžaduji nejvyšši pozornost a je to Zákonodárce, který má povinnost s takovou pozorností se pokoušet a vylepšovat tyto podmínky". ${ }_{4}$ Regulace sociální agendy vedla $\mathrm{k}$ nárůstu státní intervence, která rozšířila působnost státních orgánů do oblastí dosud regulovaných mimoprávně. Rozvojem principu právního státu a zásady legality výkonu veřejné moci došlo k navýšení legislativní produkce a její obsahové dynamiky. Parlament, orgán, který v historických obdobích zasedal jen jednou i za několikaleté období, nyní zasedá téměř nepřetržitě, přestože mu v normativní činnosti pomáhají i úrady spadající do moci výkonné. Giandomenico Majone upozorňuje, že vznik fenoménu nezávislých správních úřadů je potřeba přičítat potřebě odborného zajištění dlouhodobých politik, které politici shromáždění v parlamentu nemohou zastávat: „S vědomím bližicí se změny mají politici jen malou motivaci hledat řěseni problému, jehož odstranění se projeví až po př̌ištich volbách. $Z$ toho di̊vodu je pro politiky složité se snažit o dlouhodobá řešení. Druhým problémem je model kolektivního rozhodování, kde se možné hlasovaci většiny mění a je nutné stále sledovat veškeré zájmy jednotlivých skupin." ${ }^{5}$

Celkově tak růst regulatorního státu a globalizační procesy spojené s normotvorbou tvořenou na ministerské úrovni vedou k posilování moci výkonné na úkor parlamentu. ${ }^{6}$ Aby parlament mohl tomuto posunu konkurovat a zvrátit jej, dochází k tvorbě kazuis-

2 LESAFFER, R. European legal history: a cultural and political perspective. Cambridge: Cambridge University Press, 2009, s. 22 a násl.

3 RADBRUCH, G. O napětí mezi účely práva. Praha: Wolters Kluwer, 2012, s. 147-148 a 152.

4 VAN AEKEN, K. From Vision To Reality: Ex Post Evaluation of Legislation. Legisprudence, 2015, Vol. 5, Iss. 1, s. 46, DOI: 10.5235/175214611796404859.

5 MAJONE, G. From the Positive to the Regulatory State: Causes and Consequences of Changes in the Mode of Governance. Journal of Public Policy, 1997, Vol. 17, Iss. 2, s. 153.

6 CORKIN, J. Constitutionalism in 3D: Mapping and Legitimating Our Lawmaking Underworld. European Law Journal, 2013, Vol. 19, Iss. 5, s. 642. 
tických zákonů, které na jedné straně snižují míru volnosti výkonné moci, ${ }^{7}$ ale zároveň nejsou s to postihnout předvídat veškeré životní situace. To vede k novelizacím předpisů, jež jsou spojeny s rizikem dalších chyb a nedomyšleností; tedy $\mathrm{k}$ multiplikaci popisovaného problému. Právo se tak stále rychleji mění a přestává být pro své adresáty předvídatelné. Na pomyslné ose stability práva se tímto dostáváme do opačného extrému, než je př́isná rigidita práva, a to do jeho př́lišné fluidity.

Problémem dynamické společnosti je nerovnost této dynamiky. Zatímco pomyslný „obyčejný občan“ musí být zděšen z rychlosti a počtu změn v legislativě, osoby pohybující se na prríklad v oblasti technologického průmyslu takové změny musí považovat za př́iliš pomalé. Bez odpovídající regulace dojde k umělému zamrazení stavu vedoucímu k zastavení kreativni destrukce 8 a stagnaci inovací. Mike Turley tak např́íklad upozorňuje na potřebu rychleji přijímaných předpisů za účelem úpravy řady nových společenských trendů pro férovější fungování trhu. Na druhou stranu zdůrazňuje, že se nemá jednat o bezhlavou snahu, ale o aktivitu mnohem více disciplinovanou než dosud a vedoucí k promýšlené, plánované a adaptabilní regulaci. ${ }^{9}$ Nejedná se přitom o nijak revoluční myšlenku - Jiří Grospič o řadu let dřive vyzýval k tomu samému „,... je potřebné vycházet z toho, že legislativní proces vypracování a přijímání legislativních aktů má dlouhodobějši charakter a že proto právní regulace není vhodným prostředkem pro dosažení krátkodobých politických úkolů, má stanovit dlouhodobě pưsobicí pravidla, která odpovídají požadavkům právní jistoty. Z toho naopak vyplývá požadavek, aby regulatorni politika byla plánována pro delši období..." ${ }^{10}$ Aby toho zákonodárce mohl dosáhnout, musí mít k tomuto cíli odpovídající legislativně-technické nástroje.

\section{STÁVAJÍCÍ SITUACE}

Kritika zákonodárné činnosti by měla být nicméně předkládána v kontextu určité statistiky. Nejvíce vhodným se autorovi zdá volba analýzy nedávno uzavřeného sněmovního cyklu, tzn. 7. volební období, byt' bylo oproti dvěma předchozím volebním obdobím netypické $\mathrm{v}$ tom směru, že po celou jeho dobu existovala jen jedna vláda opírající se o stabilní sněmovní většinu. $Z$ toho důvodu mohlo být $\mathrm{k}$ legislativní činnosti využito celé volební období a nedocházelo $\mathrm{k}$ zásadní personální diskontinuitě ve formě obměny celé vlády, což umožňuje představit data o legislativním procesu bez potřeby významnějších korektivů. Zároveň jde o poslední uzavřené volební období, takže nejlépe může ukazovat trendy současného zákonodárství:

7 LAMOUROUX, S. La codification ou la démocratisation du droit. Revue française de droit constitutionnel, 2001/4, No. 48, s. 801-824, DOI: 10.3917/rfdc.048.0801.

8 Viz ACEMOGLU, D. - ROBINSON, J. A. Proč státy selhávaji: kořeny moci, prosperity a chudoby. Praha: Argo, 2015.

9 VEJVODOVÁ, A. Zákony by se měly měnit častěji. Právní rádce, 2019, č. 5.

10 GROSPIČ, J. Podněty OECD a Asociace pro legislativu ke zkvalitnění právní regulace. In: VOSTRÁ, L. ČERMÁKOVÁ, J. (eds.). Otázky tvorby práva v České republice, Polské republice a Slovenské republice: sbornik př́spěvků z mezinárodního vědeckého sympozia ,Aktuální otázky tvorby práva v České republice, Polské republice a Slovenské republice“, Praha, 29.-30. 11. 2004. Plzeň: Vydavatelství a nakladatelství Aleš Čeněk, 2005, s. 147. 
Ze 639 návrhů zákonů jich bylo v 7. volebním období schváleno Parlamentem 353, takže připadá v průměru přibližně 90 schválených zákonů na každý rok. $Z$ celkového počtu zákonů jich 372 předložila Poslanecké sněmovně vláda, 236 zákonů předložili poslanci a 23 návrhů zákonů předložil Senát. Logicky neúspěšnější se svými návrhy byla vláda opírající se o sněmovní většinu, které se podařilo prosadit 300 jejích návrhů (80,6 \%), a osm svých návrhů prosadil Senát (34,8 \%). Relativně neúspěšní jsou poslanci prosadivší 44 návrhů (18,6 \%) a zastupitelstva krajů (12,5\%, 1 z 8 návrhů). Nejčastěji - v 294 předložených návrzích - dochází k novelizaci jen jednoho zákona, nicméně v průměru návrhy novelizují 4 stávající zákony, což je dáno zejména doprovodnými novelami přijímanými v souvislosti s přijetím nového samostatně stojícího zákona. Tím se významně mění průměr oproti mediánu. Nejrozsáhlejší novelou 7. volebního období je tak zákon č. 183/2017 Sb. měnící 256 zákonů v souvislosti s reformou přestupkového práva.

Samostatných nových zákonů, tzn. nesoucích vlastní kodexový obsah a novelizujících nejvýše jeden jiný stávající zákon, je poměrně málo $-\mathrm{v} 7$. volebním období jich bylo schváleno pouze 22 . Lze tedy poněkud zjednodušeně tvrdit, že pozorujeme převážně vnitřní dynamiku, tzn. změny stávajících zákonů, nikoli expanzi právního ráádu ve formě jeho rozšiřování o nové zákony. Poslední uvedené je nicméně potřeba korigovat $z$ důvodu špatně kvantifikovatelného fenoménu pozměňovacích návrhů. Pokud opomeneme 31 př́padů, kdy Poslanecká sněmovna schválila návrh zákona v prvním čtení, tj. bez možnosti podávat pozměňovací návrhy, zbývá nám 359 návrhů zákonů, které postoupily do druhého čtení. $Z$ toho $\mathrm{v} 332$ př́padech byl $\mathrm{k}$ návrhu předložen alespoň jeden poslanecký pozměňovací návrh. U 66 návrhů navíc došlo $k$ dalšímu předložení pozměňovacích návrhů ze strany Senátu a jejich vrácení Sněmovně, která Senátu převážně vyhověla. Ve výsledku tak je omezení se na konstatování počtu návrhů a jejich úspěšnost přijetí zavádějící, protože zákonodárci mění právní řád velkou měrou skrze pozměňovací návrhy a nikoli skrze samostatné novely.

Uvedený vzorek údajů ukazuje, že přestože povětšinou nedochází k zásadní expanzi právního řádu, občan čelí poměrně rozsáhlé novelizační aktivitě, která navíc poměrně rychle nabývá účinnosti. Téměř polovina (162) zákonů vstoupila v účinnost 15 nebo méně dní od svého vyhlášení. Významná část zákonů je zpracována $\mathrm{v}$ gesci Ministerstva financí ČR, tudíž část zákonů směřuje ke změně daňových povinností. Praxe vydávání částek sbírky zákonů v posledním prosincovém týdnu, tedy v posledních dnech starého roku, také nepřispívá právní jistotě adresátů. Vedle návrhů na změnu zákona o dani z prŕjmů (35 návrhů) a zákona o spotřební dani (12 návrhů) jsou oblíbenými cíli zákonodárcových snah o změnu zákony z oblasti práva sociálního zabezpečení zákon o důchodovém pojištění ( 24 návrhů) či zákon o veřejném zdravotním pojištění (18 návrhů). Jedná se opět o zákony, jejichž účel je redistribuce bohatství společnosti dle záměrů zákonodárce, tedy významně zasahující do sféry práv a povinností občanů. Neslavným rekordmanem novelizačních snah je nicméně občanský soudní řád, k jehož změně směřovalo 36 předložených návrhů.

Uvedená zvolená metoda neumožňuje postihnout rozsah změn v jeho reálných konturách: například sněmovní tisk č. 647, vládní návrh zákona o změně některých zákonů v souvislosti s prrijetím zákona o sbírce zákonů a mezinárodních smluv, sice novelizuje 
66 zákonů, ale většinou jde o úpravu změny názvu sbírky zákonů. Svým rozsahem kratší zákony naopak mohou mít mnohem větší dopad na životy běžných občanů, hospodářské prostředí i délku parlamentních deliberací, jako je zákon č. 340/2015 Sb., o zvláštních podmínkách účinnosti některých smluv, uveřejňování těchto smluv a o registru smluv, který měnil jen jeden jiný zákon a ve svém vlastním textu obsahuje jen deset paragrafů. Zvolená metoda nicméně umožňuje poukázat na všeobecně tvrzený argument, ${ }^{11}$ že zákony nejsou dlouhodobě plánovány a koncepčně tvořeny. Zejména se to projevuje v samostatných novelách či ve skutečnosti, že několik zákonů přijatých v 7 . volebním období bylo ještě v jeho průběhu zrušeno či novelizováno.

\section{CHYTRÁ DOČASNOST ZÁKONU゚}

Abychom se mohli bavit o chytré dočasnosti zákonů, je potřeba si vymezit, co si pod tímto pojmem máme představit. Tradiční model legislativy představuje schéma, ve kterém je předpis přijat $\mathrm{v}$ perpetuální podobě, tzn. plné a úplné, aniž by zákon sám předznamenával své zrušení nebo změnu. Ukončení existence zákona může mít pak dvě podoby - první je kodifikace a druhou je právní reforma: Kodifikace spočívá v nahrazení právního předpisu formálně novým předpisem, přestože nedochází k žádným nebo jen marginálním materiálním změnám. ${ }^{12}$ Opačnou cestou se zákonodárce vydává $\mathrm{v}$ prípadech reformy vedoucí $\mathrm{k}$ materiální diskontinuitě, tedy právní úprava obsahově dále nepokračuje a nová pravidla chování vychází z jiných tezí či zadání. V některých př́padech sice může docházet $\mathrm{k}$ formální kontinuitě předpisu, ale komplexní novela ponechá na svém místě jen sbírkové číslo. Terminologicky může být toto rozlišení matoucí, protože české názvosloví zpravidla spojuje rekodifikaci kodexových zákonů s jejich reformou, tj. nejedná se primárně o nové uspořádání, ale o jejich změnu. Zde je potřeba upozornit, že autor dále užívá termín rekodifikace pro českou terminologii nestandardně, tj. ve smyslu shromáždění roztř́šstěné právní úpravy, doktríny i judikatury do jednoho přehledně uspořádaného předpisu, což je v souladu se zahraniční terminologií.

V některých př́ípadech kodifikovat ani zásadně reformovat není možné nebo vhodné - rychlý rozvoj technologií a přechod na digitální ekonomiku neumožňuje stanovovat rigidní pravidla, protože se proměňuje rychleji, než probíhá legislativní proces a regulace je tedy bud' neefektivní, nebo rdousící investice. Lepší je tak někdy využít experimentální legislativy a na omezených vzorcích vyzkoušet př́nosnost právní úpravy řešení různých problémů. $\mathrm{V}$ praxi je experimentální legislativa používána např́íklad

11 Vedle řady odborných textů je možné poukázat na usnesení stálé komise pro Ústavu a parlamentní procedury Senátu č. 10 z její 10. schůze v 5. funkčním období dne 12. ledna 2006: „,.. problémem závažnějším než sám objem právní regulace [je] její nestabilita, tj. četnost a charakter novelizací zákonů, kterou v našem prípadě nelze spojovat pouze s polistopadovou transformací společnosti a s integrací do Evropské unie, ale predevším s nedostatečně koncepčni tvorbou zákonů již v exekutivě...".

12 Autor vychází z názvosloví obecně užívaných v zahraničí, což může být pro českého čtenáře zavádějící, nebot' v Česku je reforma právního odvětví označována za rekodifikaci. Srovnej LAMOUROUX, S. La codification ou la démocratisation du droit. Op. cit. nebo VOERMANS, W. - MOLL, C. - FLORIJN, N. - VAN LOCHEM, P. Codification and Consolidation in the European Union: A Means to Untie Red Tape. Statute Law Review, 2008, Vol. 29, Iss. 2, s. 66, DOI: 10.1093/slr/hmn007. 
v Nizozemsku nebo v Německu. ${ }^{13}$ Francie má zmocnění k experimentální legislativě dokonce zahrnuto v čl. 37-1 francouzské ústavy. Z historie může být př́kladem českého legislativního experimentu nasazení Všeobecného občanského zákoníku rakouského v oblasti rakouské Haliče v roce 1797 před jeho všeobecným uzákoněním pro celou monarchii (s výjimkou uherských zemí) v roce 1811. Ze současných legislativních experimentů je možné poukázat na medializovaný finský pokus o reformu sociálního systému skrze minimální nepodmíněný př́ijmem, ve kterém asi 2000 náhodně vybraných finských nezaměstnaných dostávalo měsíčně 560 eur. Byl při tom zkoumán vliv této dávky na sociální a pracovní návyky nezaměstnaných. Pokud je experimentální legislativa úspěšná, může být univerzálně aplikována na celou společnost. Pokud se naopak neosvědčí a nesplní slibovaný efekt, může být automaticky opuštěna a pokusný segment se vrátí do obecného režimu právní úpravy.

$\mathrm{K}$ tomuto automatizovanému procesu slouží zejména klauzule dočasnosti či stmívací klauzule (sunset clause), která předpokládá skutečnost, na jejímž základě dojde ke zrušení daného právního předpisu. Nejjednodušším příkladem je běh času, tedy zrušení zákona po uplynutí určitého časového úseku. Mohou být ale i sofistikovanější konstrukce, jako je dosažení cíle zákona či nastání jiné předvídané skutečnosti. V takových př́ípadech musí být nicméně exaktně stanoven zpưsob ověření vzniku takové skutečnosti. Stmívací klauzule dále vytvářejí tlak na zákonodárce, aby konal, protože taková klauzule i laikovi signalizuje, že se jedná o provizorní právní úpravu. V praxi by totiž legislativní provizorium mohlo trvat nepřiměřeně dlouho. V českých reáliích na takové provizorium absence plnohodnotné úpravy správního soudnictví musel reagovat až Ústavní soud svým derogačním nálezem. ${ }^{14}$

Vzhledem ke skutečnosti, že neexistuje konstrukce odpovědnosti za zákonodárnou nečinnost, ${ }^{15}$ stmívací klauzule tento problém pomáhá řešit. Její určitou modifikací je revizní klauzule (review clause), která zákonodárci dává povinnost vyhodnocovat a přehodnocovat funkčnost právních předpisů pod sankcí jejich zrušení, pokud se parlament neusnese na opaku. Parlament si díky tomu může na výkonné moci vynucovat pravidelné zpracování statistik o aplikaci právní úpravy (monitoring), zprávu o dosavadní efektivitě regulace (controling) nebo právě hodnocení účinnosti regulace (ex post evaluation), ${ }^{16}$ čímž ji dostává pod tlak. Nejedná se tak nově o jednosměrný proces chrlení nových předpisů, ale cyklus vytváření, hodnocení a korekce legislativních aktů. Tato

13 Pro další př́íklady viz VAN GESTEL, R. - VAN DIJCK, G. Better Regulation through Experimental Legislation. European Public Law, 2011, Vol. 17, Iss. 3, s. 542 a násl.

14 Viz nález sp. zn. Pl. ÚS 16/99: „Není sporu o tom, že způsob obnovení správního soudnictví novelou o.s.řr. v roce 1991 byl chápán v době svého vzniku jako dočasné rešení, s vědomím nezbytnosti provedení celkové rekodifikace řizení a vytvořeni smysluplné soustavy správnich soudů. Vzhledem $k$ tomu, že v krátké době byly bez výhrad prijaty závazky vyplývajicí z Úmluvy... stalo se zminěné provizorium v mnoha bodech ještě problematičtějším."

15 HÖLLANDER, P. Odpovědnost státu za „legislativní újmu“ aneb postmoderní záměna právní a politické odpovednosti. In: TICHÝ, L. - HRÁDEK, J. Odpovédnost státu za legislativni újmu. Praha: Centrum právní komparatistiky Právnické fakulty Univerzity Karlovy v Praze, 2012, s. 67 a násl. Srovnej ŠIMÍČEK, V. Opomenutí zákonodárce jako porušení základních práv. In: DANČÁK, B. - ŠIMíČEK, V. (eds.). Deset let Listiny základních práv a svobod v právním rádu České republiky a Slovenské republiky. Brno: Masarykova univerzita, Mezinárodní politologický ústav, 2001, Sborníky č. 6, s. 145-146.

16 WIRTHS, D. Procedural Institutionalization of the Evaluation Through Legal Basis: A New Typology of Evaluation Clauses in Switzerland. Statute Law Review, 2016, Vol. 38, Iss. 1, s. 25, DOI: 10.1093/slr/hmv033. 
cyklická podoba více odpovídá projektovému chápání legislativní tvorby, která je více cílena na výsledek (goal oriented). Toto pojetí koresponduje s kontrolní funkcí parlamentu, jež musí být posilována vzhledem $\mathrm{k}$ sílící roli exekutivy v normativní oblasti (viz výše). Posilovaní kontrolní funkce se na príklad promítlo do novely čl. 24 francouzské ústavy, která v roce 2008 Národnímu shromáždění uložila věnovat část jednacího týdne vyhodnocování platných předpisů.

V některých př́padech vzniká opačná situace, než je nečinnosti, tedy zákonodárce předpokládá vznik určité skutečnosti a reaguje na ni bez jistoty jejího vzniku. Nevznikne-li nicméně předpokládaný stav, předpis sám obsahově vyhasne a stane se obsolentním, čemuž má opět možnost pomoci stmívací klauzule. Tuzemským př́kladem je zrušovací ustanovení zákona č. 74/2019 Sb., o úpravě některých vztahů v souvislosti s vystoupením Spojeného království Velké Británie a Severního Irska z Evropské unie, který obsahuje autozrušovací ustanovení pro př́pad, že by nedošlo k vystoupení Spojeného království z EU, nebo by se tak stalo na základě vzájemné dohody. Tato stmívací klauzule tak napomáhá správě právního řádu a jeho purizaci, nebot' nejen že se takový předpis nepoužije, ale nebude ani součástí právního rrádu, což posiluje právní jistotu adresátů.

Důležité také je, že iniciativa je $\mathrm{v}$ př́ípadě obou variant stmívacích klauzulí v rukou zákonodárce, který je nucen rozhodnout o rozšíření nebo prodloužení experimentu pod sankcí derogace. ${ }^{17}$ Do takového režimu se na př́klad dostávají ty britské podzákonné předpisy, které přinášejí zvýšení nákladů podnikatelskému nebo občanskému sektoru. Každý takový předpis je $\mathrm{v}$ pětiletém cyklu opakovaně přezkoumáván z pohledu jeho př́nosnosti občanské společnosti nebo podnikatelskému sektoru. Př́ílušné ministerstvo ohledně svých závěrů sestavuje zprávu včetně variant možných řešení a budoucích postupů, která je zveřejněna na jeho internetových stránkách. ${ }^{18}$ Odpovědná ministerstva jsou tedy samotným předpisem nucena se mu v pravidelném intervalu znovu věnovat a sledovat, zda se nejedná o již prékonanou právní úpravu či úpravu, která je zbytečně zatěžující.

\section{DOČASNOST CHTĚNÁ A NECHTĚNÁ}

Velkou otázkou klauzulí je právní jistota a předvídatelnost právního řádu, nebot' jejich použití může vést $\mathrm{k}$ nejistotě, zda dané pravidlo bude ještě třeba za pár dní vymáháno či nikoli. Zda např. parlament zařadí prodloužení určitého předpisu vůbec na svou schůzi, nebo zda se předpis nestane obětí obstrukcí. Je také zřejmé, že stmívací klauzule mohou být uplatněny $\mathrm{v}$ př́padech zvláštní úpravy, vedle které existuje obecná právní úprava, byt' ne optimální, která by se aktivovala v případech uplatnění stmívací klauzule bez dalšího. Nelze si tedy na př́klad představit, že by takovou klauzulí byl stižen celý občanský zákoník, ale zřejmě by nic nebránilo tímto způsobem upravit kupní smlouvu pro internetové obchody. Koncept stmívacích klauzulí je také vhodný pro

17 Více k tomu RANCHORDAS, S. Sunset Clauses and Experimental Regulations: Blessing or Curse for Legal Certainty? Statute Law Review, 2015, Vol. 36, Iss. 1, s. 29, DOI: 10.1093/slr/hmu002.

18 VB. $§ 28$ odst. 2 písm. a) Small Business, Enterprise and Employment Act 2015. Dostupné z: http://www .legislation.gov.uk/ukpga/2015/26/part/2/crossheading/secondary-legislation-duty-to-review [naposledy navštíveno 15. 11.2018]. 
mimořádné situace, např. zvláštní „,povodňové“ daně nebo opatření ke stabilizaci veřejných rozpočtů, kde dávají adresátům určitou jistotu, že nedojde ke skryté transformaci mimořádného pravidla do pravidla univerzálně platného. ${ }^{19}$ Již nyní takové klauzule ve své podstatě obsahuje krizový zákon, který podmiňuje trvání určitého mimořádného stavu souhlasem nebo potvrzením ze strany některého orgánu.

Klauzule temporality ve spojení s ex post evaluací má zejména smysl u regulace moderních technologií - nové postupy v bioinženýrství nebo ve výzkumu lidského genomu budí celou řadu etických i právních otázek. Jako jistější řešení se proto může zákonodárci zdát varianta určité postupy preventivně zakázat. Podobné rozhodnutí má nicméně výrazné dopady na inovativnost a konkurenceschopnost ekonomiky, takže vhodnější je úpravu přijmout ve zkušebním režimu a př́ípadně ji ve světle zjištěných skutečností korigovat nebo uběhnutím určeného času nechat „umřitt“.

Cynickým argumentem proti námitce narušení právní jistoty adresátů je také realita běžných zákonů: Je otázkou k zamyšlení, zda předem ohlášená dočasnost regulace nevzbuzuje u regulovaných subjektů větší důvěru než praxe neočekávaného sledu novel, jak tomu je u běžného zákona. Oto Novotný k tomuto uvádí, že vzhledem ke komplexnosti společenských vztahů, do kterých zákon zasahuje, je každý zákon vlastně zvláštním druhem experimentu. ${ }^{20}$ Dočasnost předpisu s sebou také nese naději, že potenciálně rušená úprava se nestane terčem nesouvisejících př́lepků, i její novelizace jsou méně pravděpodobné.

\title{
5. ZÁVĚR
}

Cílem tohoto textu bylo představení stmívacích klauzulí, jakožto sofistikovaných nástrojů umožňujících lépe využívat různé modely účinnosti právních předpisů. Oproti např. dělené účinnosti stmívací klauzule nejsou v tuzemsku téměř využívány a zřejmě ani známy. Každý nástroj je samozřejmě jen tak užitečný, jako dobrý je řemeslník, který jej používá, ale byla by škoda je v české legistice opomíjet. Stmívací klauzule samy nevyřeší neduhy českého právního řádu, ale umožňují zákonodárci vytvářet chytrou právní úpravu, která nerdousí ani neomezuje proměnu společnosti. A pokud se stane, že regulace rdousící efekt má, pak bude zrušena i bez zdlouhavého projednávání parlamentem.

\author{
JUDr. Michal Ř́ha \\ Právnická fakulta Univerzity Karlovy \\ rihamich@prf.cuni.cz \\ ORCID: 0000-0001-9227-2158
}

19 Asi nejslavnějším zákonem postaveným na sunset clause je americký Uniting and Strengthening America by Providing Appropriate Tools Required to Intercept and Obstruct Terrorism Act of 2001, známý pod svou zkratkou PATRIOT Act 2011. Zákon exekutivu zmocňuje k užívání celé palety zvláštních pravomocí k potírání terorismu, nicméně díky temporální klauzuli postupně vypadla kontroverzní ustanovení např̀. umožňující všeobecné a nerozlišující sledování ze strany Národní bezpečnostní agentury (NSA). Bylo samozřejmě možné daná ustanovení vypustit zvláštní novelou, ale omezená časová působnost a obrácení potřeby shánět hlasy pro prodloužení dostávají vládu pod tlak, aby udělala ústupky nebo přišla o celý zákon.

20 NOVOTNÝ, O. Hypertrofie práva, její aspekty a jak jí čelit. Právník, 2007, roč. 155, č. 7, s. 623. 